\title{
7. Are We Keeping the Bastards Honest? Perceptions of corruption, integrity and influence on politics
}

\author{
Clive Bean
}

The words of the late Don Chipp, the founder of the Australian Democrats, have perennial relevance to politics. When Chipp talked about 'keeping the bastards honest', it related to a minor political party playing a role of keeping the major political parties true to their word (Warhurst 1997). Yet it is also a democratic role that citizens play on an ongoing basis, particularly through the mechanism of elections. At the ballot box, governments that are widely perceived to have acted with a lack of integrity are roundly punished. This chapter explores public opinion on issues of integrity, corruption, influence and trust in politics and politicians in Australia. The evidence paints a differentiated picture of a public which sees little sign of overtly corrupt political practices but on the other hand does not feel terribly influential and is not always confident of fair treatment from public officials.

Corruption and corrupt practices occur in a variety of manifestations and contexts (Heywood 1997). Australia is not known for the widespread institutional corruption prevalent in some nations. Although there has been no shortage over the years of instances of minor misdemeanours, corrupt practices tend to occur more in the form of individual or personal corruption rather than in a systematic, institutionalised form within structures of governance. In other words, a politician seeks to gain an illegitimate advantage from his or her position in a particular instance, not as an ongoing practice. Institutional corruption, involving systematic abuse of process, is certainly not unknown in Australia, particularly at the level of State politics (Beresford 2010), but it could not be said to be common practice in the way it is in some societies.

There are also, of course, degrees of dishonesty when it comes to the behaviour of politicians and the Australian public appears to have some level of resigned acceptance of political deceit and perhaps even an expectation of it. We are all used to politicians who promise something without qualification and then claim that circumstances have changed when they fail to deliver. A well-known example is that of former Prime Minister John Howard who, as Leader of the Opposition in the mid-1990s, claimed that the Coalition would 'never, ever' introduce a goods and services tax (GST), following its failure to win election on a GST platform in 1993. A few years later, having won office, the Howard 
Government did in fact introduce a GST (Warhurst and Simms 2002). To a large extent, the Australian public took this change of mind in its stride on this occasion. Indeed, a clever politician can sometimes promote a change of heart as a virtue: they have seen the shortcomings of their prior position and are now acting squarely in the public interest.

Yet there is little doubt that integrity is regarded as an integral facet of good governance. Previous research into citizen perceptions of honesty and integrity in Australian politics has found, among other things, that the public expects higher ethical standards from politicians than politicians expect from themselves (McAllister 2000). It has also been shown that elections are widely regarded as serving their purpose well and ensuring that voters' views are represented, and further that corruption is not seen as very widespread (Bean 2009). On the other hand, as in so many countries, in Australia trust in politicians is modest at best (Bean 2005), and indeed some have argued that it has reached levels low enough to be of real concern (Martin 2010).

This chapter reviews evidence from the 'Role of Government' module in the 2007 Australian Survey of Social Attitudes (AuSSA) on questions of perceived corruption in politics and experiences of corruption, on questions of fair treatment and personal influence and on questions of efficacy and trust. Particular questions it will consider include how widespread political corruption is perceived to be, direct experience of corrupt practices, how fairly and honestly public officials deal with ordinary citizens, the amount and nature of influence members of the public have on political decision making and on politics and governance in general. The chapter will also consider the extent to which dispositions on these matters are related to a variety of other factorsfor example, whether education generates greater political confidence and reduced scepticism. Importantly, it will also look at whether a person's sense of societal connectedness relates to views about political corruption and fairness of political treatment.

\section{Perceptions of corruption, integrity and influence}

The 'Role of Government' module in the 2007 AuSSA contains a series of questions probing public perceptions of the extent of political corruption and personal experience of it. The survey respondents are asked: 'In your opinion, about how many politicians in Australia do you think are involved in corruption?' The question is then asked again for public officials. The results are displayed in Table 7.1. The pattern of responses is fairly similar for the two and it is loaded towards a perception of relatively little corruption in Australian politics. Some 9 per cent say almost none and another 35 per cent say a few 
politicians are involved in corruption (making a total of 45 per cent who more or less dismiss the issue as a problem in Australia). When the 38 per cent who say 'some' are added, this leaves only 17 per cent (one in six) who believe that quite a lot (14 per cent) or almost all (3 per cent) politicians are involved in corruption.

Table 7.1 Perceptions of Corruption in Australian Politics, 2007 (per cent)

\begin{tabular}{lrrrrr}
\hline & $\begin{array}{c}\text { Almost } \\
\text { none/ } \\
\text { a few }\end{array}$ & Some & Quite a lot/almost all & Total & (N) \\
\hline $\begin{array}{l}\text { Politicians involved in } \\
\text { corruption }\end{array}$ & 45 & 38 & 17 & 100 & (2492) \\
$\begin{array}{l}\text { Public officials involved } \\
\text { in corruption }\end{array}$ & 41 & 41 & 18 & 100 & (2492) \\
\hline & Never & Seldom & $\begin{array}{l}\text { Occasionally/quite } \\
\text { often/very often }\end{array}$ & Total & (N) \\
\hline $\begin{array}{l}\text { Instances of public official } \\
\text { wanting bribe or favour }\end{array}$ & 88 & 8 & 4 & 100 & (2637) \\
\hline
\end{tabular}

Note: No. $=2781$.

Source: Australian Survey of Social Attitudes 2007.

Switching the focus to appointed public officials, rather than elected politicians, makes little difference to the pattern of responses, although the attitude towards public servants is if anything slightly less benign: 41 per cent say almost none or a few public officials are involved in corruption and 18 per cent say quite a lot or almost all are. But overall, as befits a political system in which known cases of corruption are much more the exception than the rule, the balance of public opinion is stacked heavily against any notion of political corruption being commonplace in Australia.

When the questioning becomes more specific and refers to respondents' own experiences of instances of public officials wanting a bribe or favour (in the past five years) the response is even more emphatic (Table 7.1). The question reads: 'In the last five years, how often have you or a member of your immediate family come across a public official who hinted they wanted, or asked for, a bribe or favour in return for a service?' Almost nine out of 10 (88 per cent) say they have never been subjected to such a situation in the past five years, while virtually no-one says it has happened 'very often'. Indeed, we can add three differentiated answer categories together ('Very often', 'Quite often' and 'Occasionally') and still only make 4 per cent of the sample. In sum, corruption does not appear to be seen by the public as a major problem in Australian politics.

That citizens are not overly concerned about the level of corruption, though, does not necessarily mean that they are not concerned about integrity in 
Australian politics. Acting with integrity can obviously be a more subtle matter than simply not being overtly corrupt. The initial questions in Table 7.2 are about how people feel they are treated by public officials. The first question - 'In your opinion, how often do public officials deal fairly with people like you?' — shows a less benign view of political dealings. Fewer than half ( 46 per cent) feel that public officials deal fairly with people like them 'almost always' or 'often'. One-third think that public officials only deal fairly with people like them 'occasionally' and another 22 per cent say 'seldom' or 'almost never'. In other words, more than half the sample feel that in general they are not treated fairly by public officials.

Table 7.2 Perceptions of Fair Dealing and Influence in Australian Politics, 2007 (per cent)

\begin{tabular}{lrrrrrr}
\hline & $\begin{array}{r}\text { Almost } \\
\text { always/ } \\
\text { often }\end{array}$ & Occasionally & $\begin{array}{r}\text { Seldom/ } \\
\text { almost never }\end{array}$ & Total & (N) \\
\hline $\begin{array}{l}\text { Public officials deal fairly with } \\
\text { people like you }\end{array}$ & 46 & 32 & 22 & 100 & (2497) \\
\hline & Definitely & Probably & $\begin{array}{r}\text { Probably not/ } \\
\text { definitely not }\end{array}$ & Total & (N) \\
\hline $\begin{array}{l}\text { Treatment from public officials } \\
\text { depends on who people know }\end{array}$ & 29 & 51 & 20 & 100 & (2566) \\
\hline & Never & Seldom & $\begin{array}{r}\text { Occasionally/ } \\
\text { often }\end{array}$ & Total & (N) \\
\hline $\begin{array}{l}\text { How often asked to influence } \\
\text { important decisions in other } \\
\text { people's favour }\end{array}$ & 39 & 33 & 28 & 100 & (2674) \\
\hline & Nobody & A few & Some/a lot & Total & (N) \\
\hline $\begin{array}{l}\text { People you could ask to help } \\
\text { influence important decisions in } \\
\text { your favour }\end{array}$ & 40 & 44 & 15 & 100 & (2607) \\
\hline
\end{tabular}

Note: No. $=2781$.

Source: Australian Survey of Social Attitudes 2007.

In addition there is a strong sense of the 'it's not what you know but who you know' syndrome. In response to the question 'Do you think that the treatment people get from public officials in Australia depends on who they know?', 29 per cent of AuSSA respondents say that it definitely does and another 51 per cent say it probably doesfour out of five, in other words, think who you know matters. And within the 20 per cent with a more positive outlook, only 2 per cent are confident that treatment people receive from public officials definitely does not depend on who they know.

The bottom two questions in Table 7.2 are about respondents' relationship to the 'who you know' category. The first question is: 'Some people, because of their job, position in the community or contacts, are asked by others to help influence 
important decisions in their favour. What about you? How often are you asked to help influence important decisions in other people's favour?' Most people have little if any experience of being asked to wield political influence. Just less than four in 10 say they are never asked and another third say seldom. Another 24 per cent say occasionally and only 4 per cent say they are often asked to help influence important decisions in other people's favour. Most people are not asked and most people do not know anyone they could ask to wield influence for them. In response to the second question - And are there people you could ask to help influence important decisions in your favour?' - 40 per cent say 'no, nobody', a further 44 per cent say 'a few', while only 15 per cent say 'some' or 'a lot' (and those who say 'a lot' number only 1 per cent). Thus, while respondents believe that receiving good treatment depends on having the right connections, most do not feel that they have such connections.

If these data suggest a sense of powerlessness, such a sense is further reinforced when we explore perceptions of political efficacy in Table 7.3. Research has shown that there are two forms of political efficacy: external efficacy, which is about how responsive governments and politicians are to the public; and internal efficacy, the sense of ability to participate in politics competently and effectively (Abramson 1983; Craig and Maggiotto 1982; Hayes and Bean 1993). More than half the AuSSA 2007 respondents agree with the proposition that 'People like me don't have any say about what the government does', while only a little more than one-quarter disagree, with the remainder neither agreeing nor disagreeing. A related question produces a similar result: nearly six in 10 (58 per cent) disagree with the notion that 'the average citizen has considerable influence on politics' with only one in five agreeing and the rest (22 per cent) sitting in the middle.

Table 7.3 Perceptions of Efficacy and Trust in Australian Politics, 2007 (per cent)

\begin{tabular}{|c|c|c|c|c|c|}
\hline & $\begin{array}{r}\text { Strongly } \\
\text { agree/ } \\
\text { agree }\end{array}$ & $\begin{array}{l}\text { Neither } \\
\text { agree nor } \\
\text { disagree }\end{array}$ & $\begin{array}{r}\text { Disagree/ } \\
\text { strongly } \\
\text { disagree }\end{array}$ & Total & (N) \\
\hline $\begin{array}{l}\text { People like me don't have any say } \\
\text { about what the government does }\end{array}$ & 53 & 19 & 28 & 100 & (2484) \\
\hline $\begin{array}{l}\text { The average citizen has considerable } \\
\text { influence on politics }\end{array}$ & 20 & 22 & 58 & 100 & (2672) \\
\hline $\begin{array}{l}\text { I feel I have a pretty good } \\
\text { understanding of the important } \\
\text { issues facing our country }\end{array}$ & 65 & 22 & 13 & 100 & (2674) \\
\hline $\begin{array}{l}\text { I think most people are better } \\
\text { informed about politics than I am }\end{array}$ & 18 & 36 & 46 & 100 & (2665) \\
\hline $\begin{array}{l}\text { People we elect as MPs try to } \\
\text { keep the promises they have made } \\
\text { during the election }\end{array}$ & 27 & 29 & 44 & 100 & (2670) \\
\hline $\begin{array}{l}\text { Most public servants can be trusted } \\
\text { to do what is best for the country }\end{array}$ & 30 & 34 & 36 & 100 & (2671) \\
\hline
\end{tabular}

Note: No. $=2781$. 
The sense of citizen efficacy is much stronger, however, when the focus is on political information and understanding. Nearly two-thirds (65 per cent) feel that they 'have a pretty good understanding of the important issues facing our country', while only 13 per cent feel that they do not (with a further 22 per cent being unsure). This expression of competence is reinforced by the fact that only 18 per cent think that 'most people are better informed about politics than I am'. Some 46 per cent disagree with this proposition with a further 36 per cent unsure. These findings replicate the results from earlier rounds of the AuSSA (Bean and Denemark 2007).

When it comes to questions of trust and honesty, opinion is divided and tends towards the sceptical. When asked whether they agree that 'people we elect as MPs try to keep the promises they have made during the election', 44 per cent disagree, 29 per cent neither agree nor disagree and only 27 per cent agree. A slightly greater proportion agree that 'most public servants can be trusted to do what is best for the country', while 34 per cent neither agree nor disagree and 36 per cent disagree. The AuSSA respondents, then, are ambivalent about how much trust they can place in politicians and public officials and many feel lacking in political influence, but they are fairly confident of their own political knowledge and understanding.

\section{Societal underpinnings}

Previous studies have shown that certain key socio-demographic variables influence perceptions of political integrity, efficacy and trust. A frequent finding is that education plays a crucial role in breaking down public suspicion of the political elite (Bean 2005; Bean and Denemark 2007; McAllister 2000). Gender and age often seem to play a role in shaping such attitudes as well. Another important factor is social capital - the sense of connectedness or integration into society that grows out of community networks, norms and trust (Putnam 2000). In this instance societal connectedness is represented by a question on social trust, in which respondents are asked to what extent they agree or disagree that 'if you are not careful, other people will take advantage of you'. Social trust, by this measure, is not high in Australia, with more than two-thirds of the sample (69 per cent) agreeing that there is a danger of other people taking advantage, while 17 per cent neither agree nor disagree and only 14 per cent adopt a confidently trusting stance by disagreeing with the proposition.

Each of Tables 7.4, 7.5 and 7.6 takes a key variable from Tables 7.1, 7.2 and 7.3 and breaks it down by these four socio-demographic indicators. Table 7.4 looks at perceptions of how many politicians are involved in corruption. A small amount of variation by sex is apparent, but it is very modest. Women are 
7. Are We Keeping the Bastards Honest? Perceptions of corruption, integrity and influence on politics

slightly less likely than men to say that almost none or only a few politicians are involved in corruption and very slightly more likely to say that quite a lot or almost all are. If anything women are thus marginally more concerned about the prevalence of political corruption in Australia, but there is very little in it. Age does not differentiate the respondents to any great degree either. Older people, however, are a little more benign and the young a little more suspicious. The university educated are somewhat more inclined to say that none or few politicians are involved in corruption than those without a university degree, but again the differences are modest.

\section{Table 7.4 Perceptions of Corruption by Socio-Demographic Characteristics (per cent)}

\begin{tabular}{|c|c|c|c|}
\hline Politicians involved in corruption: & $\begin{array}{r}\text { Almost none/ } \\
\text { a few }\end{array}$ & Some & $\begin{array}{r}\text { Quite a lot/ } \\
\text { almost all }\end{array}$ \\
\hline \multicolumn{4}{|l|}{ Sex } \\
\hline Female $(n=1272)$ & 43 & 39 & 18 \\
\hline Male $(n=1202)$ & 47 & 38 & 16 \\
\hline \multicolumn{4}{|l|}{ Age } \\
\hline Under 35 ( $n=456)$ & 41 & 40 & 19 \\
\hline $35-49(n=711)$ & 43 & 38 & 19 \\
\hline $50-64(n=766)$ & 47 & 36 & 17 \\
\hline 65 and over $(n=527)$ & 47 & 40 & 13 \\
\hline \multicolumn{4}{|l|}{ Education } \\
\hline No university degree $(n=1829$ ) & 43 & 39 & 17 \\
\hline University degree ( $n=599)$ & 49 & 36 & 15 \\
\hline \multicolumn{4}{|l|}{ Social trust } \\
\hline \multicolumn{4}{|c|}{ If you are not careful, other people will take advantage of you } \\
\hline Agree $(n=1688)$ & 40 & 39 & 21 \\
\hline Neutral ( $n=393$ ) & 53 & 37 & 10 \\
\hline Disagree $(n=338)$ & 56 & 36 & 8 \\
\hline
\end{tabular}

Note: No. $=2781$.

Source: Australian Survey of Social Attitudes 2007.

Differentiation is more apparent by social trust. Those who are most trusting of people generally are also substantially more likely to give politicians the benefit of the doubt than those who score lower on social trust. Some 56 per cent of those who display trust say few or no politicians are involved in corruption and only 8 per cent say most are. By contrast, 21 per cent of those who lack trust think most politicians are involved in corruption - two-and-a-half times the proportion of the trusting - and only 40 per cent say virtually none is. 
Next we return to the issue of how people are treated by public officials, specifically the question of whether the treatment people get depends on who they know. Table 7.5 shows that on this question there are no gender differences to speak of and relatively small differences by age. The oldest cohort of respondents - those sixty-five and over - seems somewhat more committed than the remainder to the view that who you know matters.

Table 7.5 Perceptions of Treatment from Public Officials by SocioDemographic Characteristics (per cent)

\begin{tabular}{|c|c|c|c|}
\hline $\begin{array}{l}\text { Treatment from public officials } \\
\text { depends on who people know: }\end{array}$ & Definitely & Probably & $\begin{array}{l}\text { Probably not/ } \\
\text { definitely not }\end{array}$ \\
\hline \multicolumn{4}{|l|}{ Sex } \\
\hline Female $(n=1324)$ & 29 & 53 & 19 \\
\hline Male $(\mathrm{n}=1222)$ & 28 & 51 & 21 \\
\hline \multicolumn{4}{|l|}{ Age } \\
\hline Under $35(n=469)$ & 27 & 54 & 19 \\
\hline $35-49(n=726)$ & 27 & 52 & 21 \\
\hline $50-64(n=791)$ & 30 & 48 & 23 \\
\hline 65 and over $(n=542)$ & 30 & 54 & 16 \\
\hline \multicolumn{4}{|l|}{ Education } \\
\hline No university degree $(n=1893)$ & 31 & 52 & 17 \\
\hline University degree $(n=605)$ & 19 & 51 & 30 \\
\hline \multicolumn{4}{|l|}{ Social trust } \\
\hline \multicolumn{4}{|c|}{ If you are not careful, other people will take advantage of you } \\
\hline Agree $(n=1778)$ & 34 & 51 & 15 \\
\hline Neutral $(n=402)$ & 16 & 57 & 27 \\
\hline Disagree $(n=358)$ & 15 & 46 & 39 \\
\hline
\end{tabular}

Note: No. $=2781$.

Source: Australian Survey of Social Attitudes 2007.

Both education and social trust make a marked difference to responses on this question. Whereas 30 per cent of those with a university degree state that who you know probably or definitely does not make a difference to the treatment received from public officials, only 17 per cent of those without university education think likewise. The figures are more or less reversed for those who say who you know definitely does make a difference: 31 per cent of those without a university degree give this response, while only 19 per cent of those with a degree do also. The contrast is even greater between those who differ on social trust. Nearly four in 10 of the trusting (39 per cent) say that treatment from public officials probably or definitely does not depend on who you know compared with 15 per cent of the untrusting. And again the balance is reversed for the group saying treatment definitely does depend on who you know: 34 per cent of the untrusting say it does compared with only 15 per cent of the trusting. 
Table 7.6 Perceptions of Political Efficacy by Socio-Demographic Characteristics (per cent)

\begin{tabular}{|c|c|c|c|}
\hline $\begin{array}{l}\text { People like me don't have } \\
\text { any say about what the } \\
\text { government does: }\end{array}$ & $\begin{array}{r}\text { Strongly } \\
\text { agree/agree }\end{array}$ & $\begin{array}{r}\text { Neither agree } \\
\text { nor disagree }\end{array}$ & $\begin{array}{r}\text { Disagree/strongly } \\
\text { disagree }\end{array}$ \\
\hline \multicolumn{4}{|l|}{ Sex } \\
\hline Female $(n=1393)$ & 52 & 20 & 29 \\
\hline Male $(n=1270)$ & 55 & 19 & 26 \\
\hline \multicolumn{4}{|l|}{ Age } \\
\hline Under $35(\mathrm{n}=498)$ & 50 & 20 & 30 \\
\hline $35-49(n=768)$ & 48 & 20 & 32 \\
\hline $50-64(n=822)$ & 54 & 18 & 29 \\
\hline 65 and over $(n=559)$ & 63 & 19 & 18 \\
\hline \multicolumn{4}{|l|}{ Education } \\
\hline No university degree $(n=1981)$ & 58 & 19 & 23 \\
\hline University degree $(n=632)$ & 38 & 18 & 44 \\
\hline \multicolumn{4}{|l|}{ Social Trust } \\
\hline \multicolumn{4}{|c|}{ If you are not careful, other people will take advantage of you } \\
\hline Agree $(n=1809)$ & 59 & 17 & 24 \\
\hline Neutral $(n=439)$ & 43 & 28 & 29 \\
\hline Disagree $(n=366)$ & 34 & 19 & 47 \\
\hline
\end{tabular}

Note: No. $=2781$.

Source: Australian Survey of Social Attitudes 2007.

A cynic might be tempted to say that the university educated and the socially trusting have more benign views because they have the right kinds of political connections to ensure good treatment, so they can afford to say who you know does not matter. Indeed, the AuSSA data show that there is some correlation, though small, between holding a degree and knowing people who may be able to help influence political decisions. A corrective to this perspective, however, is that even among the university educated and socially trusting sizeable majorities still hold the view that treatment from public officials does depend on who you know: seven in 10 of the university educated and six in 10 of the trusting. Thus, while concern about political treatment is reduced among those with a university degree, for example, it is far from completely transformed.

Last, we focus again on political efficacy, with Table 7.6 showing the sociodemographic breakdown of the question about how much say ordinary citizens have about what the government does. Again, gender differences are slim, although women appear to have a slightly stronger sense of efficacy than men. Age, however, does make a difference to feelings of efficacy. Younger people are considerably more likely to feel efficacious than older people. The clearest contrast is between those under the age of fifty and those sixty-five and over. 
About half of those under fifty agree that 'people like me don't have any say about what the government does' but of those sixty-five and over nearly twothirds do. And while 30 per cent or more of those under fifty disagree with the proposition, only 18 per cent of those sixty-five and over disagree.

Once again education and social trust give rise to the most marked differences. Nearly six in 10 of those without a university degree lack a sense of political efficacy while less than four in 10 of those with a university qualification express a similar lack of efficacy. On the other hand, 44 per cent of the university educated display a sense of efficacy compared with only 23 per cent of those who are less well educated. Similarly, those who are not socially trusting also tend to lack political efficacy (59 per cent display a lack of efficacy and only 24 per cent show a sense of efficacy), while those who do trust others are much more inclined to feel politically efficacious ( 47 per cent display a sense of efficacy and only 34 per cent lack a feeling of efficacy). In the sample as a whole the ratio of the non-efficacious to the efficacious is almost two to one (53 per cent versus 28 per cent). But for both the highly educated and the socially trusting, this balance is overturned so that more people in these groups express a sense of efficacy than a lack of efficacy.

\section{Conclusion}

The evidence in this chapter paints a mixed picture. While there is no indication that political corruption is perceived to be a major problem among the Australian public, there is a good deal of concern about how fairly people are treated by public officials and about a perceived lack of external political efficacy - that is, a lack of governmental responsiveness and a sense of inability to have any influence. On the other hand, internal efficacy - feeling politically competentis very high. This contrast between low external efficacy and high internal efficacy is not an isolated finding (Bean and Denemark 2007).

Perhaps the most important finding to emerge from this study is the difference that education and social capital make to perceptions about politics. This is not the first time that the significance of education has been highlighted, both in Australia and elsewhere (Bean 2009; Hayes and Bean 1993; McAllister 2000). The implications for governance and for public policy development are important and worth discussing. Education appears to lessen the sense of suspicion and negativity inherent in many people's orientations towards politics. Governments thus have a vested interest in pursuing policies to enhance the educational stocks of the nation. The more people who undertake a university education the more barriers will be broken down between the political elite and the public; 
likewise with social capital. Building strong communities in which citizens feel connected with and trusting of each other has many benefits, one of them being that it will help improve public perceptions of the political realm.

Yet neither education nor social capital is a panacea. The data show that education generally changes attitudes to an extent, not completely. Many welleducated people remain unconvinced of the benignity of the political world. And there are no doubt good reasons for this, reasons that would relate among other things to actual experiences of governmental non-responsiveness. Taken to its extreme, the argument about education would suggest that the problem is entirely one of perceptions, and with a thoroughly well-educated community no-one would have a low sense of political efficacy, for example. In reality of course governments and politicians are far from totally responsive to every citizen's political requirements and it would be almost impossible for them to be so. Nonetheless, education and the knowledge it generates do help make the realm of politics more accessible and less daunting for individuals.

Are we keeping the bastards honest? The evidence suggests that the answer is a qualified 'yes'. Corruption in politics is not widely perceived to be rampant and, perceptions aside, very few individuals have personal experience of corruption. Yet at a more diffuse level, many Australians feel relatively powerless in the political arena, they are concerned that people with the right connections will get more favourable treatment from public officials and they are not confident that elected politicians and appointed public officials can be trusted.

\section{References}

Abramson, Paul R. 1983. Political Attitudes in America. San Francisco: W. H. Freeman.

Bean, Clive. 2005. 'Is there a crisis of trust in Australia?'. In Australian Social Attitudes: The first report, eds Shaun Wilson, Gabrielle Meagher, Rachel Gibson, David Denemark and Mark Western. Sydney: UNSW Press.

Bean, Clive. 2009. 'Public perceptions of elections: an Australia-New Zealand comparison'. In In the Public Interest: Essays in honour of Professor Keith Jackson, eds M. Francis and J. Tully. Christchurch: Canterbury University Press.

Bean, Clive and Denemark, David. 2007. 'Citizenship, participation, efficacy and trust in Australia'. In Australian Social Attitudes 2: Citizenship, work and aspirations, eds David Denemark, Gabrielle Meagher, Shaun Wilson, Mark Western and Timothy Phillips. Sydney: UNSW Press. 
Beresford, Quentin. 2010. 'Corporations, government and development: the case of institutional corruption in Tasmania'. Australian Journal of Political Science 45: 209-25.

Craig, Stephen C. and Maggiotto, Michael A. 1982. 'Measuring political efficacy'. Political Methodology 8: 85-110.

Hayes, Bernadette C. and Bean, Clive S. 1993. 'Political efficacy: a comparative study of the United States, West Germany, Great Britain and Australia'. European Journal of Political Research 23: 261-80.

Heywood, Paul (ed.). 1997. Political Corruption. London: Blackwell.

McAllister, Ian. 2000. 'Keeping them honest: public and elite perceptions of ethical conduct among Australian legislators'. Political Studies 48: 22-37.

Martin, Aaron. 2010. 'Does political trust matter? Examining some of the implications of low levels of political trust in Australia'. Australian Journal of Political Science 45: 705-12.

Putnam, Robert D. 2000. Bowling Alone: The collapse and revival of American community. New York: Simon \& Schuster.

Warhurst, John (ed.). 1997. Keeping the Bastards Honest: The Australian Democrats' first twenty years. Sydney: Allen \& Unwin.

Warhurst, John and Simms, Marian (eds). 2002. 2001: The centenary election. Brisbane: University of Queensland Press. 